This manuscript is a non peer-reviewed preprint, it is under review at Journal of Climatology. 
Enriching the historical meteorological information using Romanian newspaper reports

Short title: Historical meteorological information in Romania

S Cheval (1, 2, 3)*, A Haliuc* (3, 4, 5), B Antonescu (6), A Tișcovschi (7), M Dobre (7), F Tătui (7), A Dumitrescu (2, 3), A Manea (2), G Tudorache (7,8), A Irimescu (2), M-V Birsan (2), C Mock (9)

(1) “Henri Coandă” Air Force Academy, Faculty of Aeronautical Management, Braşov, Romania

(2) National Meteorological Administration, Bucharest, Romania

(3) Research Institute of the University of Bucharest, University of Bucharest, Bucharest, Romania

(4) Charles University, Faculty of Mathematics and Physics, Prague, Czech Republic

(5) University of Suceava, Faculty of History and Geography, Suceava, Romania

*Correspondence:

Aritina Haliuc, Research Institute of the University of Bucharest, 36-46 Bd. M. Kogalniceanu, 5th

District, 050107 Bucharest, Romania, E-mail: aritina.haliuc@icub.unibuc.ro aritinahaliuc@gmail.com

Sorin Cheval, "Henri Coandă" Air Force Academy, Strada Mihai Viteazul 160, Brasov 500187, Romania, E-mail: sorin.cheval@afahc.ro; sorincheval@yahoo.com

Keywords: historical climatology, climate of the past, newspaper information, $19^{\text {th }}$ century, climate change

Abstract. Data recovery and climate reconstruction are an important support for climate change research, as they provide information from periods and areas with sparse meteorological networks. Various sources are currently in use for obtaining valuable evidences about the climate of the past, e.g. historical archives, ship logs or church documents. This study exploits newspaper reports in order to enrich the historical meteorological information over the territory of Romania, from the last two decades of the $19^{\text {th }}$ century. The digital archive of three newspapers (România Liberă, Gazeta de Transilvania and Foaia Poporului) was investigated and the meteorological information was extracted and aggregated into a database containing 2132 unique entries. Each entry represents a meteorological event and several associated characteristics, such as date and location, impact and source. A verification procedure consisting of comparison with available measurements from the nearby weather stations was applied in order to validate the entries. The results show that the meteorological information was often present in the newspapers of the epoch. Some climatic features could be retrieved (i.e, seasonality of extreme events, thermal and precipitation characteristics). This paper demonstrates the potential of the collected information to enhance 
In the last decades, the technological progress and the increasing societal needs have demanded unprecedented spatial coverage of meteorological data, at high temporal resolution at daily timescales. The combined use of remote sensing products and ground-based sensors, the evidence retrieved from citizen observatory and media (Muller et al., 2015; Groenemeijer et al., 2017), have made the meteorological information accessible globally and in real-time. Special attention has been devoted to understanding the behaviour of extreme climatic events (e.g. drought, floods, heat waves), which are expected to occur more frequently in many regions around the world (Fischer and Schär, 2009; Seneviratne et al., 2012; Rajczak et al., 2013). High spatial and temporal resolution weather information can help improve the forecasting and to mitigate the impacts of these extreme climate events, (Seneviratne et al., 2012). However, the long-term instrumental data series necessary for climate analysis are not always currently available because of, for example, sparse meteorological networks, unsystematic development of the monitoring networks, lost archives or missing records.

As most of the national meteorological networks were established in the 19th and 20th century (Jones, 2001; Böhm et al., 2009), efforts have been directed to document past weather and weather-related events using natural archives (e.g. tree rings, lake and fluvial sediments) (Jones and Mann, 2004; Büntgen et al., 2006, 2011; Trouet, 2014; Cook et al., 2015) and written records (Brázdil, 2005; Macdonald et al., 2007; Jones, 2008; Pfister et al., 2008), in order to reconstruct climate of certain epochs.

Historical written archives include manuscripts, books, diaries, newspapers, navigation logs, clerical documents, pictures/drawings or inscriptions, which describe specific meteorological events or their impact (Brázdil et al., 2009; Pfister et al., 2008; Brönnimann et al., 2018). These archives are useful tools for reconstructing the weather conditions and climate of the last centuries based on direct and indirect observation and on human perceptions. To fill the spatial and temporal gaps in meteorological data, indirect indicators (i.e. proxies from natural archives) and historical documents have been successfully used, balance with high resolution, direct climate information (Battipaglia et al., 2010; Büntgen et al., 2011; Brönnimann et al., 2018; Mock, 2012). Historical archives also provide the opportunity to calibrate and validate the climate reconstructions with instrumental datasets and to unveil the climate-society relationship over time (Pfister et al., 2018).

Across Europe, climate reconstructions based on historical documents have a long tradition especially in Switzerland, Spain, Czech Republic, and Germany where efforts have been directed to compile databases and source collections (e.g., Euro-Climhist - https:/www.euroclimhist.unibe.ch/en/, Daux et al., 2012, McCormick et al., 2012). However, only few studies have addressed climate reconstructions based on historical documents in Eastern Europe. For example, using a large collection of historical documents retrieved by Antal Réthly, professor and director of the former National Meteorological and Earth Magnetism Institute of Hungary (Réthly, 1962, 1970, 1998, 1999), Bartholy et al. (2004) reconstructed some detailed characteristics of the climate within the Carpathian region between the $12^{\text {th }}$ and $19^{\text {th }}$ century (e.g. the seasonal frequency of warm and cold conditions). Kiss (2009) emphasized some shortcomings of the Réthly database (e.g. dating of the events, location) but these are common 
In Romania, Topor (1964) compiled historical documents (i.e. Latin sources, annals, chronicles, narratives, clerical documents, newspapers) covering roughly the past two millennia and investigated the multi-centennial frequency of dry and wet periods in the region and their effects on agriculture and society (Figure 1). Corfus (1975) published a small collection of natural (i.e. weather, floods, earthquakes, insect invasion) and social events (i.e. conflicts, education, outbreaks) from the $17^{\text {th }}$ century onwards based on old manuscripts available from the Library of Romanian Academy. Cernovodeanu and Binder (1993) indirectly analysed the climate information related to Transylvania (i.e. north-western and central part of Romania), as retrieved from historical documents of Middle Age reported mainly in the Réthly database. More recently, Dudas (1999) collected information about climatic anomalies and other events from documents issued between 1501 and 1900 for the central part of the country (i.e. Transylvania).

Newspaper and magazine articles as a proxy for primary source historic climate reconstruction have been successfully employed in climate reconstructions in different parts of the world, such as Europe (Brázdil et al., 2005), Great Britain (Taylor et al .,2015), Ireland (Murphy et al., 2017), Spain (Añel et al., 2017) and Hawaii (Businger et al., 2018). When the information is carefully selected and properly interpreted (e.g. considering an appropriate level of uncertainty or validating with other sources), its scientific utility can be supplementary in historical climatology and physical geography at different timescales. For example, focussing on information retrieved from regional newspapers issued in 2006 and 2011, Taylor et al. (2015) enriched the UK National Landslide Database with 111 records.

This paper demonstrates the climate data potential perspective based on articles/reports from three Romanian newspapers, published at the end of the $19^{\text {th }}$ century. After the Introduction (Section 1), this article is structured in four sections. Section 2 describes the characteristics of the newspaper data used. A brief description of the meteorological measurements and network and the climate of Romania of the analysed period is included in section 3. Section 4 contains the results and discussions, and section 5 summarizes the article and outlines further research directions.

103

\section{Newspaper data}

Meteorological information was manually collected from the digital collections of three newspapers issued at the end of the $19^{\text {th }}$ century in Romanian, (1) România Liberă (RL), issued at Bucharest (Romania), (2) Gazeta de Transilvania (GT), issued at Brașov, and (3) Foaia Poporului (FP), issued at

108 Sibiu. In the $19^{\text {th }}$ century, Braşov and Sibiu belonged to the Austrian-Hungarian Empire (Figure 2). The

109 dataset is published online at: https://doi.org/10.4121/uuid:2f66aeef-4227-4c5d-b239-3f6d850e1ed9

110 (Cheval et al., 2019).

111 Table 1 shows how often meteorological information used to be mentioned in the examined newspapers at the end of the $19^{\text {th }}$ century. The statistics refers only to the selected collection of events (see

113 below the description of the filtering methodology), and the relative frequency can be increased if the errors

114 and uncertainties which kept other entries out of this study are reduced. Important differences between the

115 three newspapers is clearly evident, likely as a result of editorial policies. Of importance, official reports

116 issued by the meteorological service of Romania containing observations and forecasts (Annex 1) used to 
117 be published frequently in RL, which likely influenced the interest of the public for weather. However, 118 these official meteorological reports are not utilized in this study.

119 The technical quality of the records is generally very good, the text is easy readable and with very 120 few typographic error. Each available newspaper issue was thoroughly examined and the meteorological 121 events were identified and registered in a primary database with the following structure: 1) date of the 122 meteorological event (both in Julian and Gregorian calendar); 2) location (name of the place, SIRUTA 123 code, county); 3) event (e.g. rainfall, extreme high temperature, snowfall, thunderstorm); 4) category (e.g. 124 storm, hail, flood, snowpack); 5) impacts (e.g. casualties, damages); 6) source (i.e. GT, RL, FP) and date 125 of the publication YYYYMMDD (i.e. 18890620); 7) validation (i.e. information about the event are include

126 in the records from the nearest weather station); 8) comments. The SIRUTA code 127 (http://colectaredate.insse.ro/senin/classifications.htm?selectedClassification=SIRUTA S1 2018\&action 128 =general information\&classificationName=SIRUTA\&classificationVersion=SIRUTA S1 2018) was 129 used to assign a correct and up-to-date location for each event. SIRUTA stands for Sistemul Informatic al 130 Registrului Unităților Teritorial - Administrative (Informatics System of the Territorial - Administrative 131 Units Register). SIRUTA is a classification used in Romania by the National Institute of Statistics (INS) to 132 register Administrative-Territorial Units. Each unit has a numeric code updated every six months. The 133 Territorial-Administrative Register is correlated with the Nomenclature of Territorial Statistics Units 134 (NUTS) and it is structured on three levels: 1) counties and Bucharest municipality; 2) municipalities, 135 towns, communes; and 3) localities, villages, and Bucharest sectors.

136 The quality control has been performed manually by double-checking all the entries, and a 137 consistent data set has been aggregated and submitted to the validation procedure. While concerns about 138 the credibility of the newspaper information can be always raised, validation can be approached either (1) 139 by checking the records from the closest meteorological stations whenever available (e.g. Munro and 140 Fowler, 2014) or (2) by inter-comparing the newspaper reports from different non-meteorological sources. 141 In this study, the validation consisted in checking the consistency of the newspaper reports with 142 meteorological observations from weather stations data published in Analele Institutului Meteorologic al 143 României (Annals of the Romanian Meteorological Institute) (Hepites 1885-1900) and Jahrbücher der 144 Köningl. Ung. Central-Anstalt für Meteorologie und Erdmagnetismus (1888, 1898, 1900, 1895).

\section{2. Meteorological measurements and climate of Romania at the end of the $19^{\text {th }}$ century}

147 2.1. Meteorological measurements and network in Romania

148 This overview refers to the actual territory of Romania, but we have to mention that before 1918 149 the province of Transylvania was part of the Austrian-Hungarian Empire and the meteorological network 150 was administrated accordingly. Csernus-Molnár et al. (2014) documented that the earliest long-term 18th151 century daily measurement and observation series (temperature, pressure, precipitation, sky coverage, 152 meteorological extremes) preserved in the south-eastern lowlands of the Carpathian Region at Timişoara, 153 which is in the southwest part of Romania. Few stations with meteorological measurements in Romania 154 were available during the mid-1 $9^{\text {th }}$ century (i.e. Lugoj starting in 1854, Sulina in 1857, and Satu Mare in 155 1865). In 1884 the National Meteorological Institute was founded, and 30 stations were performing 
156 meteorological monitoring systematically within the borders of Romania, while other 30 stations were in

157 function in Transylvania (Jahrbücher der Köningl. Ung. Central-Anstalt für Meteorologie und 158 Erdmagnetismus).

$160 \quad$ 2.2. Characteristics of the temperature and precipitation

161 A larger perspective about the climate of $19^{\text {th }}$ century epochs provides a framework on the use of 162 some terms in the newspaper reports. In Europe, the last two decades of the $19^{\text {th }}$ century were colder than 163 the long-term average (Luterbacher et al., 2004). Bucharest, the city where RL was issued, one can notice 164 negative temperature deviations up to $2^{\circ} \mathrm{C}$ along the whole period $1880-1900$, while at Sibiu, the city where 165 FP was issued, faced slightly colder-than-average years, (Figure 3A). The precipitation regime varied along 166 the multiannual average at both stations, with no prolonged wetness deficit or surplus (Figure 3B).

\section{Results and discussion}

169 3.1. Methodological challenges

170 The collection of the $19^{\text {th }}$ century newspaper meteorological information raised multiple issues 171 related to temporal and spatial positioning or manipulation procedures, which were addressed in order to 172 aggregate a consistent data set useful to obtain a relevant climatic perspective of the period. However, the 173 results should be regarded within the objective limits imposed by several methodological challenges.

174 First, the date of the events and newspapers are often given either the Julian or Gregorian calendar, 175 and the 12-day difference makes the time conversion difficult at the shift between months and years. The 176 moment of the occurrence of a weather event can be evasive or indirect (e.g. the day before yesterday, last 177 Friday, the Friday before Christmas), demanding dedicated attention from the investigator in order to place 178 the event in time as correct as possible.

179 Second, the locations of the events are sometimes unclear, as the name may refer either to a city 180 or to a district (e.g. Iaşi or Tulcea are both cities and districts), it could be completely changed in time (i.e. 181 Piatra Neamț is the current name for Piatra) or currently having a different spelling (e.g. Bucuresci and 182 București; Ploești and Ploiești). In cases where the location of the event was ambiguous and where the 183 event was reported in a group of localities, we have delineated the area of the event and then identify the 184 locality under question (i.e. identify the likely location of the event). We used geographical dictionaries, 185 local documents and maps for tracing the toponymical history of the localities and assign the correct name 186 and location of each event reported (i.e. Arcanum database - Települések, Dictionary of Transylvanian 187 localities, in Romania). The data set described in this study includes only locations clearly mentioned in 188 the newspapers and acknowledged today. Each location was linked to the official identifier for the 189 Romanian localities (i.e. villages and towns) per National Institute of Statistics, namely level 3 SIRUTA 190 code

191 (http://colectaredate.insse.ro/senin/classifications.htm?selectedClassification=SIRUTA_S1_2018\&action $192=$ =structure).

193 Third, the weather events were extracted in the form mentioned in the newspapers (e.g. rainfall, 194 cold day, fast snow melting), and then were grouped in several distinctive categories, resembling a content 
analysis approach commonly used by historical climatologists (Table 2). Complex phenomena (e.g.

196 blizzard, thunderstorm) were split into single phenomenon (i.e. wind and snow or, respectively heavy rain

197 and wind) in order to capture more details. The expert-based work could bias the results in this case, and

198 the multiple-iteration was applied in order to reduce the possible errors.

\subsection{Grouping the selected meteorological events in categories}

The first extraction of weather reports show that a large number of terms were used at the end of the $19^{\text {th }}$ century to communicate weather events and their consequences. Most of them are still in use in the current Romanian. The terminology was classified in several categories in order to simplify the understanding and avoid possible confusions between terms. For example, it is very likely that heavy and abundant rainfall, or strong wind and gusts have almost similar meaning for journalists and the general public, and one can include them in the same category. Table 2 presents the classification of the weather terms based on their common features, and the categories used for mapping and further analysis. Other qualitative classifications refer to:

- Reference to the impact. The reports may indicate the impacts or not. They may refer to casualties or injured people, damages or environmental consequences, and they are often put in the context of various sectors or events, such as: communication and transports (i.e. railroads, wire, postal services and naval transportation); funerals, weddings, religious holidays (i.e. Easter or Christmas) other public celebrations, crops). Some reports may be fully neutral in terms of impact, mentioning only the weather event and its characteristics (Figure 4).

- Length of the reports and level of details may vary from very short and without any details, e.g. just one sentence piece of news: "Bahluiul a debordat" - The Bahlui river has overflown - RL 1888, March 5; or "zăpada căzută ieri la Ploești are o grosime de 45 centimetre" - the thickness of the snow fallen yesterday at Ploiești reached $45 \mathrm{~cm}$ - RL 1887, February 10, to very long and sophisticated reports (i.e. one newspaper page); usually, the weather information are presented as concise reports containing significant facts, such as phenomenon, date, place and, sometimes, consequences.

- Style and language. Most reports were aligned to the journalistic writing and style, striving for brevity and objectivity. However, the reader can find more epithets, metaphors and figures of speech than in the present news feed (Figure 5).

Mass media attempts to bring describe the most impactful and spectacular events to the public as fast as possible, and the meteorological phenomena have been always a favourite topic for prime time and breaking news. The frequency of the weather and weather-related events in the selected newspapers illustrates the interest of the public, but also returns a glimpse over the climate of the epoch and the interest of the public. Apparently, at the end of the $19^{\text {th }}$ century, rainfall, storm and hail were the most powerful attention-getting phenomena, with about $70 \%$ of all weather reports identified in the selected newspapers 
233 (Figure 6). Flood, thunderstorm and blizzard phenomena (i.e. the $3^{\text {rd }}, 4^{\text {th }}$ and $5^{\text {th }}$ in terms of frequency) are

234 also related with significant precipitation, while temperature hazards have considerably lower occurrence.

236 3.4. Seasonal frequency of the weather reports in the selected publications

237 The intensity and frequency of convective events with direct and immediate impact on society

238 (e.g., tornadoes, hail, and flash floods) can generate more interest from mass media than regular weather

239 events. As a consequence, the frequency of weather reports in the selected newspapers follow a clear

240 seasonal pattern, with a maximum during the warm months (May-September, representing the convective

241 season in Romania), summing up about $82 \%$ of the total number of all events (i.e. 2132 events) (Figure 7).

242 One event may be reported in more than one locality.

243

244 3.5. Geographical distribution of the phenomena from weather reports in the selected publications

245 Most weather reports have clear indications of the geographical position, making possible to draw

246 the spatial distribution of the phenomena. Figure 8 includes all the weather events reported and show the

247 focus of each newspaper on distinct territories, considering their head offices and the interest of the readers.

248 RL focused on the eastern and southern regions containing the historical provinces Muntenia, Dobrogea

249 and Moldova (i.e. the Kingdom of Romania), and GT and FP used to report mainly events from central and

250 western Romania, namely Transylvania (i.e. part of the Austrian-Hungarian empire, at that time). One can

251 notice the very good overall geographical coverage of the reports. More details about the locations of each

252 weather category are available in Annex 2. The reports on weather events are well balanced over the

253 territory, and the high frequency of certain phenomena, such as flood, hail or rainfall (Figure 9), is

254 noticeable in their spatial distribution.

3.6. Comparison between weather information retrieved from newspaper reports and meteorological station data

Based on the results of the comparison between each newspaper report and meteorological records

260 between newspaper and data from weather stations within $20 \mathrm{~km}$-distance, at \pm 1 day lag; (2) partially

261 confirmed entries, for match between newspaper and data from weather stations within $20 \mathrm{~km}$-distance, at

$262 \pm 2$ to 5-day lag, and (3) not confirmed entries, either because meteorological data are missing or they do

263 not match with the newspaper event. The validation refers to a random sample of only 506 entries, from

264 the total number of entries, and 142 entries (28.06\%) of them were confirmed and partially confirmed.

265 Taken into account the strictness of criteria, the context and the type of the information to be compared (i.e.

266 many visual approximations and subjective information versus instrumental measurements in standard

267 conditions), one can state that we obtained a very good rate of validation.

\section{Conclusions}

270 This is the first study examining the potential of newspapers issued at the end of the $19^{\text {th }}$ century

271 to enhance the climate outlook in Romania and in South-Eastern Europe. It demonstrates that newspaper 
272 collections may disclose abundant meteorological evidence to support climate reconstruction and extreme

273 weather events down to the sub-daily timescale, especially for the pre-instrumental period and for areas with sparse networks.

In the three selected newspapers, the frequency of newspaper issues containing useful meteorological information may exceed $20 \%$, but the variations from one newspaper to another can be high.

277 The weather reports focus on high impact phenomena, such as rainfall, storm and hail, but we identified 19

278 categories of weather events present in the newspapers. The spatial distribution of the reported phenomena covers the entire territory of Romania, while the temporal regime emphasizes a higher occurrence of weather reports during the warm season.

Due to inherent uncertainties associated with such information and considerable efforts needed for obtaining valuable data, these newspaper reports have been underexploited by climate experts. There are several shortcomings which should be recognised, such as: (a) missing or incomplete information due to lack of newspaper issues in some days; (b) insufficient accuracy of information in terms of date, location and characteristics of the event (e.g. intensity, type or areal extension are not enough clear); (c) misinterpretation of the storyline due to language, low quality of the publication output; (d) difficulties to compare the outputs of newspaper collections unequal in terms of frequency, geographic coverage, or editorial policies.

Nevertheless, important benefits can be claimed for the use of newspaper information as proxysource for climatic reconstruction if thorough analysis of the data is performed, including quality checks,

291 filtering and validation. This investigation has provided useful indications about assessing the climate of Romania at the end of the $19^{\text {th }}$ century extracted from only three publications, while newspapers issued in the South-Eastern Europe in the epoch are still waiting to be explored from this perspective.

Further research will be pursued based on the findings of this paper through case studies and integration of other types of documentary data (e.g., diaries and early instrumental records), and natural paleoclimate proxies. In-depth research of each phenomenon and comparison with neighbouring areas are also expected to enhance the knowledge about the climate of the $19^{\text {th }}$ century in the central and SE Europe.

\section{Acknowledgements}

300 AH acknowledges "ICUB fellowships for young researchers". The research was [partially] supported by

301 OP RDE project No. CZ.02.2.69/0.0/0.0/16_027/0008495, International Mobility of Researchers at Charles 302 University. The authors declare that they have no conflict of interest.

\section{References}

Añel JA, Sáenz G, Ramírez-González IA, Polychroniadou E, Vidal-Mina R, Gimeno L, de la Torre L. 2017. Obtaining meteorological data from historical newspapers: La Integridad. Weather 72(12): 366371, doi:10.1002/wea.2841

Arcanum database - Települések, Dictionary of Transylvanian localities (in Romanian) [Cited 2019 March 10]. Available from: 

torteneti-es-kozigazgatasi-helysegnevtara-1/telepulesek-1C9/

Bartholy J, Pongrácz R, Molnár Z. (2004) Classification and analysis of past climate information based on historical documentary sources for the Carpathian basin. International Journal of Climatology 24(14): 1759-1776, doi: 10.1002/joc.1106.

Battipaglia G, Frank DC, Büntgen U, Dobrovolný P, Brázdil R, Pfister C, Esper J, 2010. Five centuries of Central European temperature extremes reconstructed from tree-ring density and documentary evidence. Global and Planetary Change 72: 182-191.

Böhm R, Jones PD, Hiebl J, Brunetti M, Frank D, Maugeri M. 2009. The early instrumental warm-bias: a solution for long Central European temperature series 1760-2007. Climatic Change 101(1-2): 4167, doi:10.1007/s10584-009-9649-4

Brázdil R, Pfister C, Wanner H, Von Storch H, Luterbacher J. 2005. Historical climatology in Europe- the state of the art. Climatic Change 70: 363-430.

Brázdil R, 2009. Historical climatology and its contribution to climate reconstruction in Europe. In:

324

325

326

327

328

329

330

331

332

333

334

335

336

337

338

339

340

341

342

343

344

345

346

347

348 Kirchhofer A, Krämer D, Merki CA, Poliwoda G, Stuber M, Summermatter S (eds) Nachhaltige Geschichte. Festschrift für Christian Pfister. Chronos, Zürich, 65-89.

Brönnimann S, Pfister C, White S. 2018. Archives of Nature and Archives of Societies (Chapter 3) in White S, Pfister C, Mauelshagen (2018) The Palgrave Handbook of Climate History, Palgrave Macmillan, London https://doi.org/10.1057/978-1-137-43020-5

Büntgen U, Frank D C, Nievergelt D, Esper J. 2006. Summer Temperature Variations in the European Alps, A.D. 755-2004. Journal of Climate 19: 5606-5623.

Büntgen U, Tegel W, Nicolussi K, McCormick M, Frank D, Trouet V, Kaplan JD, Herzig F, HeussneR KU, Wanner H, Luterbacher J, Esper J. 2011. 2500 years of European climate variability and human susceptibility. Science, 331(6017): 578-582. https://doi.org/10.1126/science.1197175.

Businger S, Puakea Nogelmeier M, Chinn PWU, Schroeder T. 2018. Hurricane with a history. Hawaiian Newspapers Illuminate an 1871 Storm. Bulletin of the American Meteorological Society: 137-147, 10.1175/BAMS-D-16-0333.1.

Cernovodeanu P, Binder P. 1993. Cavalerii Apocalipsului. Calamităţile naturale din trecutul României (până la 1800) (Knights of the Apocalypse. Natural disasters of Romania up to 1800). SILEX Publ. House, Bucharest 255 pp.

Cheval, S, Haliuc, A, Antonescu, B, Tiscovschi, A, Dobre, M, Tatui, F, Dumitrescu, A, Manea, A, Tudorache, G, Irimescu, A, Birsan, M-V, Mock, C. 2019. Meteorological information from Romanian newspapers of the 19th century (ROMETNEWS19). 4TU.Centre for Research Data. Dataset. https://doi.org/10.4121/uuid:2f66aeef-4227-4c5d-b239-3f6d850e1ed9

Cook ER, Seager R, Kushnir Y, R. Briffa KR, Büntgen U, Frank D, Krusic PJ, Tegel W, van der Schrier G, Andreu-Hayles L, Baillie M, Baittinger C, Bleicher N, Bonde N, Brown D, Carrer M, Cooper R, Čufar K, Dittmar C, Esper J, Griggs C, Gunnarson B, Günther B, Gutierrez E, Haneca K, Helama S, Herzig F, Heussner K-U, Hofmann J, Janda P Kontic R, Köse N, Kyncl T, Levanič T, Linderholm H, Manning S, Melvin TM, Miles D, Neuwirth B, Nicolussi K, Nola P, Panayotov M, 
Popa T, Rothe A, Seftigen K, Seim A, Svarva H, Svoboda M, Thun T, Timonen M, Touchan R, Trotsiuk V, Trouet V, Walder F, Ważny T, Wilson R, Zang C. 2015. Old World megadroughts and pluvials during the Common Era. Science Advances. 1:10, DOI: 10.1126/sciadv.1500561

Corfus I. 1975. Insemnări de demult. Junimea Publishing House, Iași 326 pp.

Csernus-Molnár I, Kiss A, Pócsik E. 2014. 18th-century daily measurements and weather observations in the SE-Carpathian Basin: A preliminary analysis of the Timişoara series (1780-1803). Journal of Environmental Geography 7(1-2):1-9, doi: 10.2478/jengeo-2014-0001.

Daux V, Garcia de Cortazar-Atauri I, Yiou P, Chuine I, Garnier E, Le Roy Ladurie E, Mestre O Tardaguila J. 2012. An open-access database of grape harvest dates for climate research: data description and quality assessment, Climate of the Past 8: 1403-1418, https://doi.org/10.5194/cp-8-1403-2012.

Dudas F. 1999 Catastrofe naturale în Transilvania. Lumina Publishing House, Oradea, 175pp.

Euro-Climhist - Ways to Weather Hindcasting [Cited 2019 April 1]. Available from: https://www.euroclimhist.unibe.ch/en/

Fischer EM, Schär C. 2009. Future changes in daily summer temperature variability: driving processes and role for temperature extremes. Climate Dynamics 33:917-935.

Groenemeijer P, Púčik T, Holzer AM, Antonescu B, Riemann-Campe K, Schultz DM, Kühne T, Feuerstein B, Brooks HE, Doswell III CA, Koppert H-J, Sausen R. 2017. Severe Convective Storms in Europe: Ten Years of Research at the European Severe Storms Laboratory. Bulletin of the American Meteorological Society 98:2641-2651.

Hepites SC. (1885-1900) Analele Institutului Meteorologic al României pe anul 1885 to 1900. Tipografia Curtii Regale, F Gobl Fii, Bucharest.

Jahrbücher der Köningl. Ung. Central-Anstalt für Meteorologie und Erdmagnetismus (1888, 1898, 1900, 1895) Central--Anstalt für Meteorologie und Erdmagnetismus Officielle Publication, Budapest.

Jones PD. 2001. Early European instrumental records. In: Jones PD, Ogilvie AEJ, Davies TD, Briffa KR (eds) History and climate: memories of the future? Plenum, New York, pp 55-77.

Jones P .2008. Historical climatology—a state of the art review. Weather 63:181-186.

Kiss A. 2009. Historical climatology in Hungary: Role of documentary evidence in the study of past climates and hydrometeorological extremes. Időjárás 113(4): 315-339.

Luterbacher J, Dietrich D, Xoplaki E, Grosjean M, Wanner H. 2004. European seasonal and annual temperature variability, trends, and extremes since 1500. Science 303: 1499-1503.

Macdonald N. 2007. Epigraphic records: a valuable resource in re-assessing flood risk and long-term climate variability. Environmental History 12:136-140.

Mackintosh AN, Anderson BM, Pierrehumbert RT. 2017. Reconstructing Climate from Glaciers. Annual Review of Earth and Planetary Sciences 45: 649-680, doi: 10.1146/annurev-earth-063016020643.

McCormick M, Harper K, More AM, Gibson K. 2013. Geodatabase of Historical Evidence on Roman and Post-Roman Climate. https://doi.org/10.7910/DVN/TVXATE, Harvard Dataverse, V4

Mock CJ. 2012. Instrumental and documentary evidence of environmental change. In: The Sage 

de Vernal, T. Denham, S.C. Fritz, and F. Oldfield, eds.), Sage Publications Ltd., London, p. 345360 .

Muller C, Chapman L, Johnston S, Kidd C, Illingworth S, Foody G, Overeem A, Leigh R. 2015. Crowdsourcing for climate and atmospheric sciences: current status and future potential. Internatonal Journal of Climatology 35: 3185-3203. doi:10.1002/joc.4210.

Munro D, Fowler A. 2014. Testing the credibility of historical newspaper reporting of extreme climate and weather events. New Zealand Geographer 70: 153-164, doi: 10.1111/nzg.12062.

Murphy C, Noone S, Duffy C, Broderick C, Matthews T, Wilby RL. 2017. Irish droughts in newspaper

Pfister C, Luterbacher J, Wanner H, Wheeler D, Brázdil R, Ge Q, Hao Z, Moberg A, Grab S, del Prieto MR. 2008. Documentary evidence as climate proxies. Proxy-specific white paper produced from the PAGES/CLIVAR workshop, Trieste, PAGES (Past Global Changes), Bern. Available from: http://www.pages-igbp.org/cgi-bin/WebObjects/products.woa/wa/product?id= 331

Pfister C, White S, Mauelshagen F. 2018. General Introduction: Weather, Climate, and Human History (Chapter 1) in White S, Pfister C, Mauelshagen (Ed) The Palgrave Handbook of Climate History, Palgrave Macmillan, London https://doi.org/10.1057/978-1-137-43020-5.

Rajczak J, Pall P, Schar C. 2013. Projections of extreme precipitation events in regional climate simulations for Europe and the Alpine Region. Journal of Geophysical Research: Atmosphere 118:3610-3626.

Réthly A. 1962. Időjárási események és elemi csapások Magyarországon 1700-ig (Weather events and natural disasters in Hungary until 1700). Akadémiai Kiadó, Budapest, 450 p.

Réthly A. 1970. Időjárási események és elemi csapások Magyarországon 1701-1800 (Weather events and natural disasters in Hungary 1701-1800). Akadémiai Kiadó, Budapest, 622 p.

Réthly A. 1998. Időjárási események és elemi csapások Magyarországon 1801-1900-ig (Weather events and natural disasters in Hungary 1801-1900). Vol. 1, Országos Meteorológiai Szolgálat, Budapest, $616 \mathrm{p}$.

Réthly A. 1999. Időjárási események és elemi csapások Magyarországon 1801-1900-ig (Weather events and natural disasters in Hungary 1801-1900). Vol. 2, Országos Meteorológiai Szolgálat, Budapest, $1369 \mathrm{p}$.

Seneviratne S, Nicholls N, Easterling D, Goodess CM, Kanae S, Kossin J, Luo Y, Marengo J, McInnes K, MRahimi M, Reichstein M, Sorteberg A, Vera C, Zhang X. 2012. Changes in climate extremes and their impacts on the natural physical environment. In: Managing the Risks of Extreme Events and Disasters to Advance Climate Change Adaptation [Field, CB, Barros V, Stocker TF, Qin D, Dokken DJ, Ebi KL, Mastrandrea MD, Mach KJ, Plattner G-K, Allen SK, Tignor M, Midgley PM (eds.)]. A Special Report of Working Groups I and II of the Intergovernmental Panel on Climate Change (IPCC). Cambridge University Press, Cambridge, UK, and New York, NY, USA, pp. 109-230.

SIRUTA (Sistemul Informatic al Registrului Unităților Teritorial - Administrative) Informatics System of the Territorial - Administrative Units Register. [Cited 2019 March 20]. Available from: 
429 Taylor FE, Malamud BD, Freeborough K, Demeritt D. 2015. Enriching Great Britain's National Landslide 430 Database by searching newspaper archives. Geomorphology 249: 52-68, doi: $431 \quad$ /10.1016/j.geomorph.2015.05.019.

432 Trouet, V. 2014. A Tree-Ring Based Late Summer Temperature Reconstruction (AD 1675-1980) for the 433 Northeastern Mediterranean. Radiocarbon, 56(4):69-78. doi:10.2458/azu_rc.56.18323

434 Topor N. 1964. Ani ploioși și secetoși în Republica Populară Română, Institutul Meteorologic Român. 435 $304 \mathrm{p}$. 


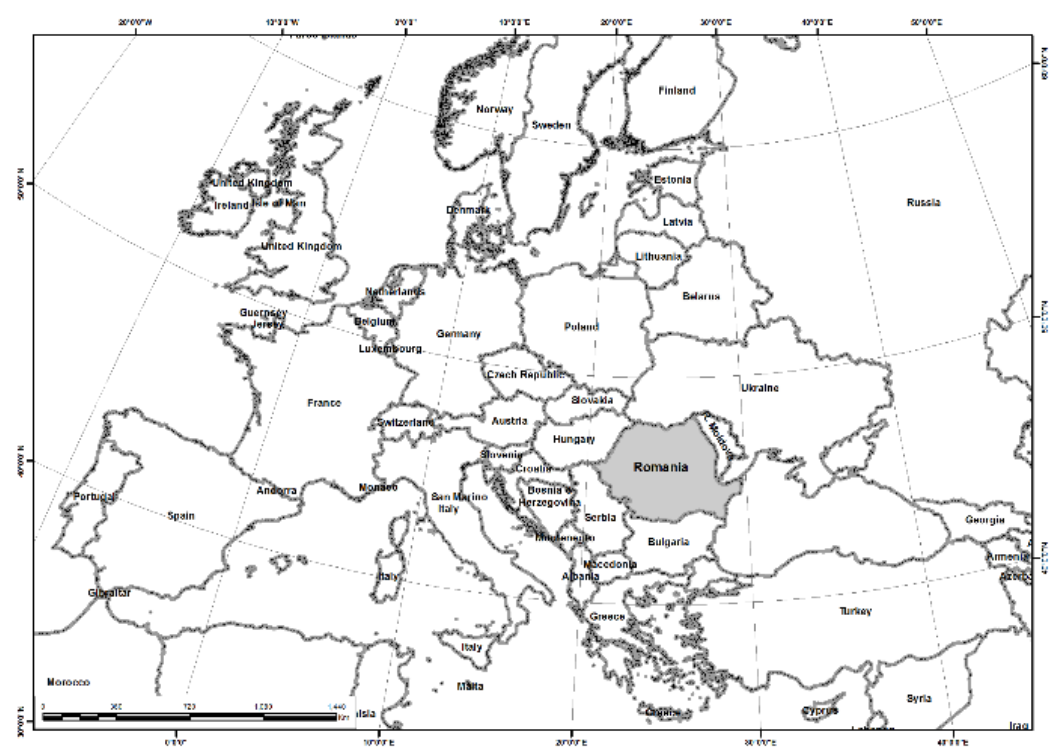

Figure 1 Romania's location in Europe (The location of the study area (Romania) in Europe)

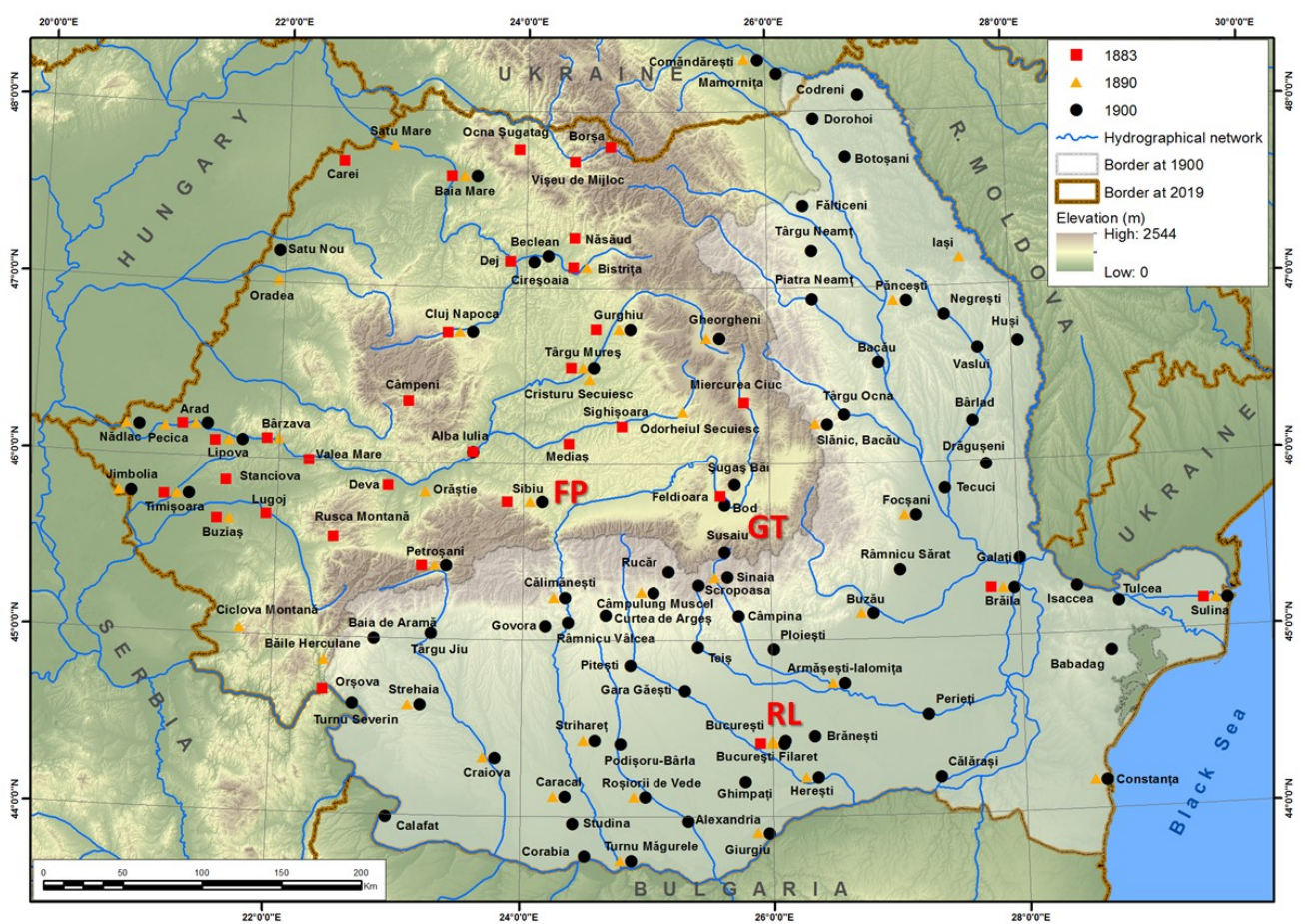
newspapers România Liberă (RL), Gazeta de Transilvania (GT), and Foaia Poporului (FP). 


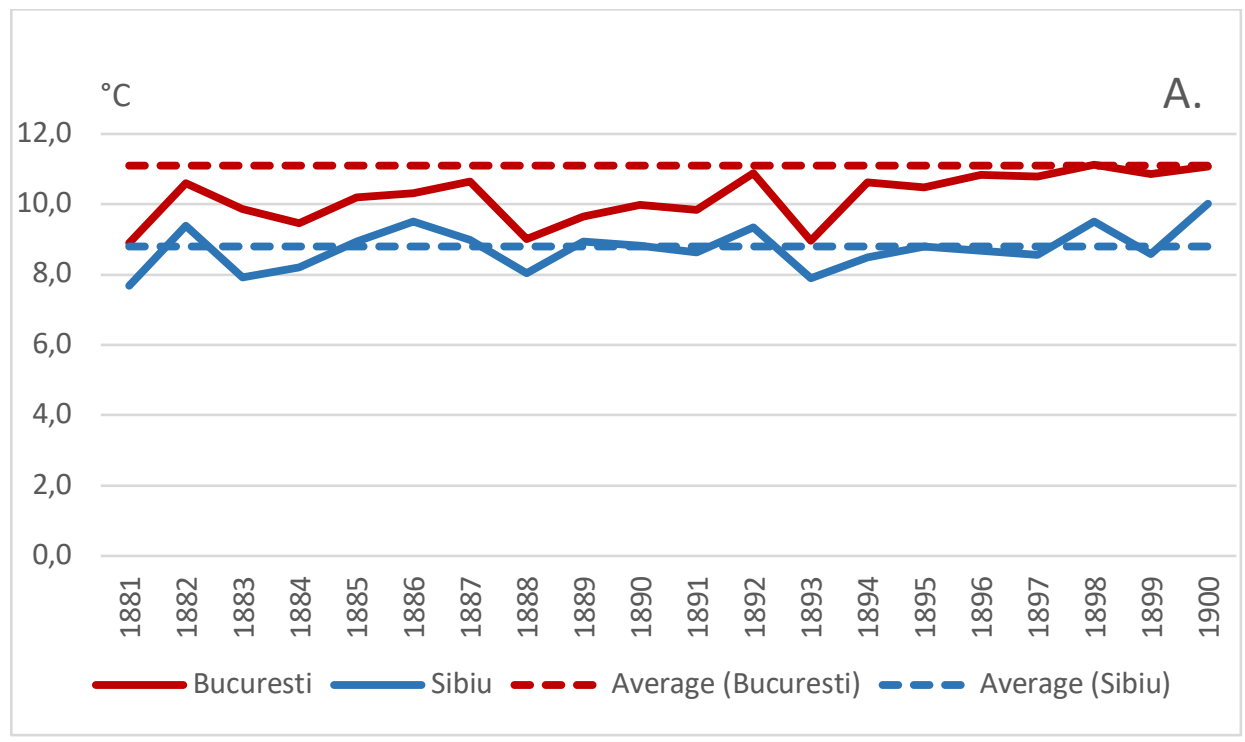

444

445

446

447

Figure 3(A) The average annual temperature and (B) precipitation at Bucharest (red line) and Sibiu (blue

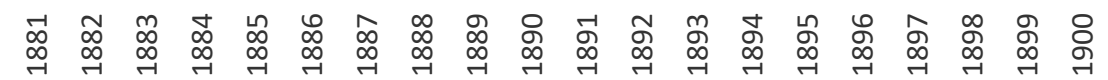

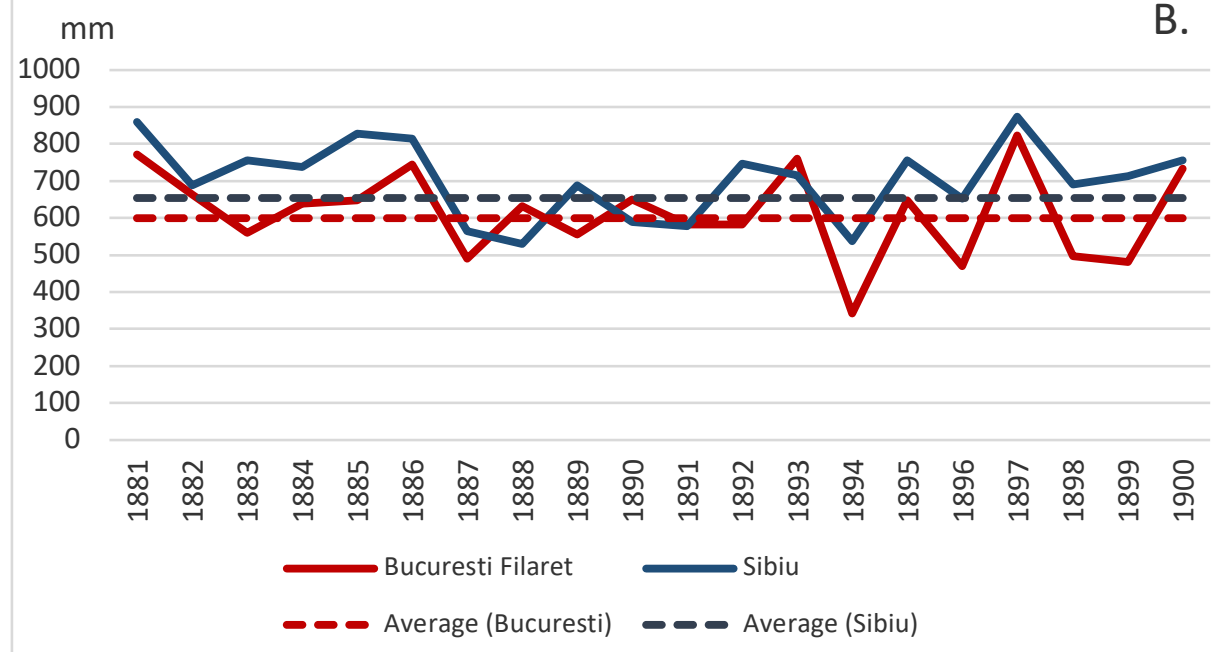
line) between 1881-1900 versus long-term annual average (1881-2015) (dashed lines).

Figure 4 Weather report from Braşov and Sibiu describing "summer rain" falling during Christmas a fostǔ moină, ba în diua de Craciunn a plouatŭ în Braşovǔ o plóiă mĕruntă ca într'o di bună de véră. ${ }_{n} \mathrm{H}$. Ztg. ${ }^{*}$ ne spune, că și în Sibiiu a plouatŭ.

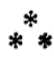

During the Christmas holiday it started to thaw, and in Brasov the Christmas day was rainy, with summer-like drizzle. The newspaper $H$. ZTG reported rain also in Sibiu. 
După o tómnæ $\stackrel{*}{*}$ atâta de frumósă și de secetósă nu era de așteptatǔ c? sø̆ fimŭ atâta de amarŭ păcăliţr de timp pulu de tómnă. Vinerr diminéța în 70 t. ne pomenimŭ cu tóte délurile Brașovuñui pline de zăpadă și cu unŭ frigŭ ne mai pomenitŭ la noi pe la începutulŭ lui Oct. Zapada și frigulŭ nicr astăd̦r n'au slabitŭ din puterea lorú.
After a warm and dry fall, one could not expect surprises. However, Friday at 7 in the morning, we found snow on all the hills around Brașov, and the bitter cold spell unusual at the beginning of October is still persistent today.
Figure 5 Weather report from Brașov city describing an unexpected snow and cold event in early October following warm and dry autumn weather (Gazeta de Transilvania, Sunday 9 (21) October 1888)

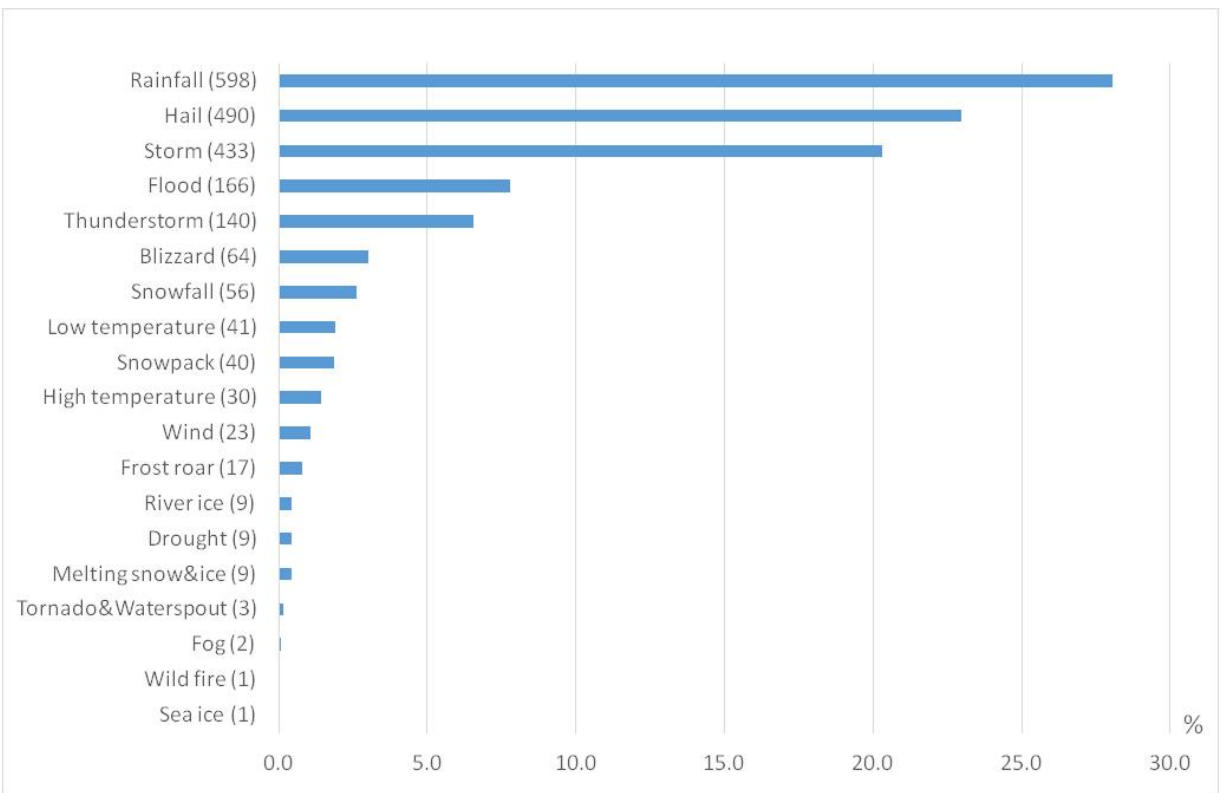

Figure 6 Absolute number (in the brackets) and relative frequency of weather and weather-related events in GT, RL and FP reports (1879-1900).

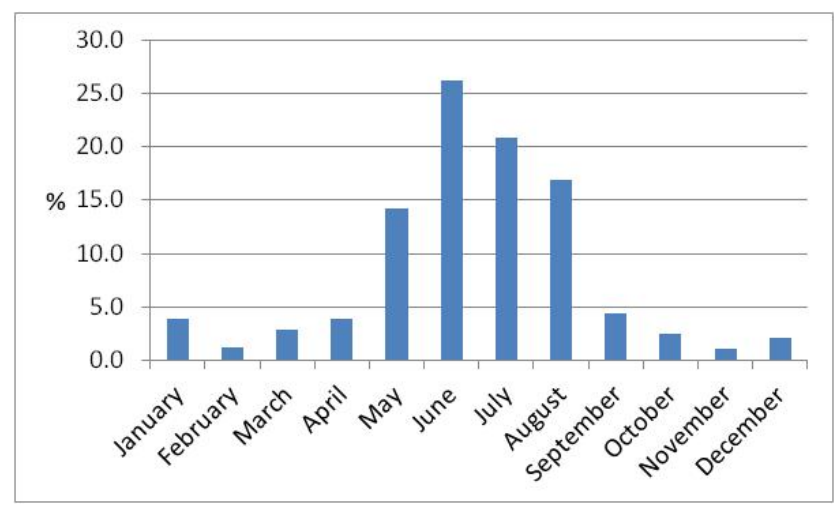

Figure 7 Monthly frequency (\%) of all the weather events mentioned in GT, RL and FP reports (18791900) 


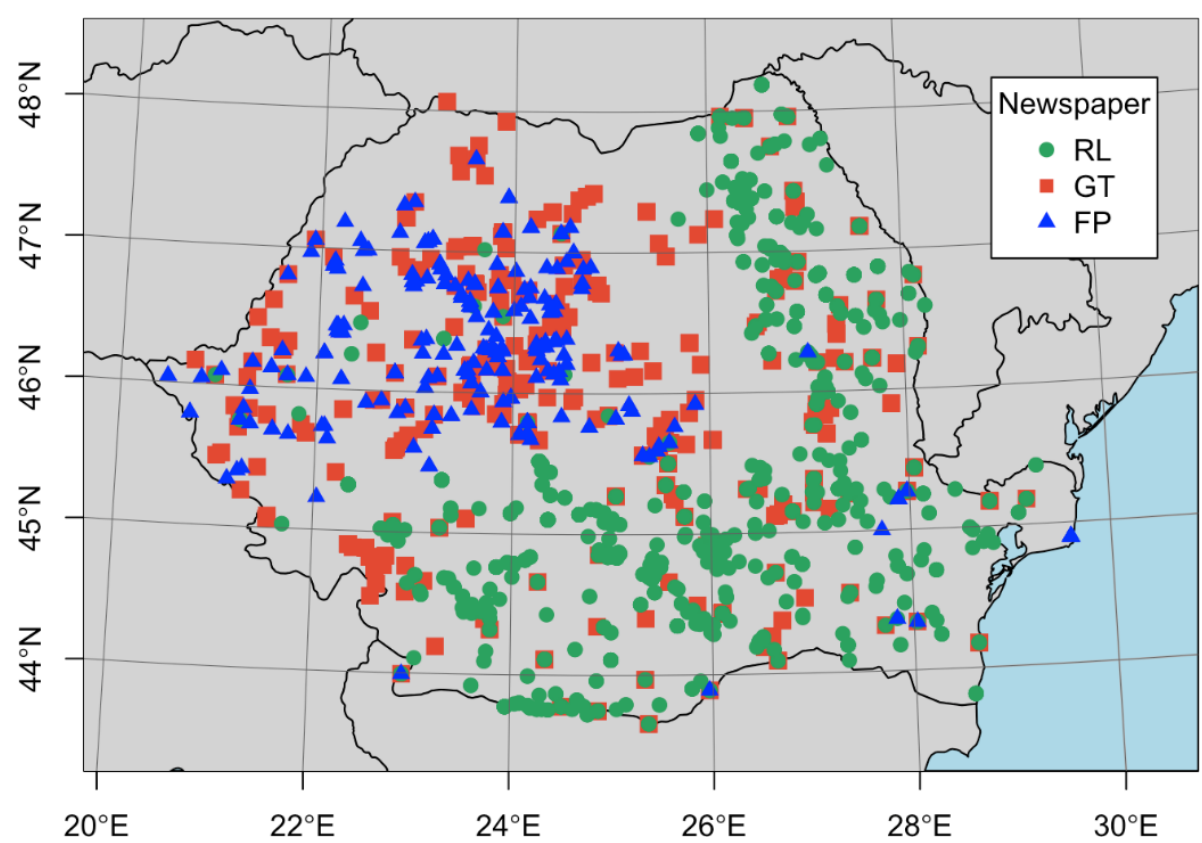

Figure 8 Spatial distribution of all-weather events mentioned in GT, RL and FP reports (1879-1900)

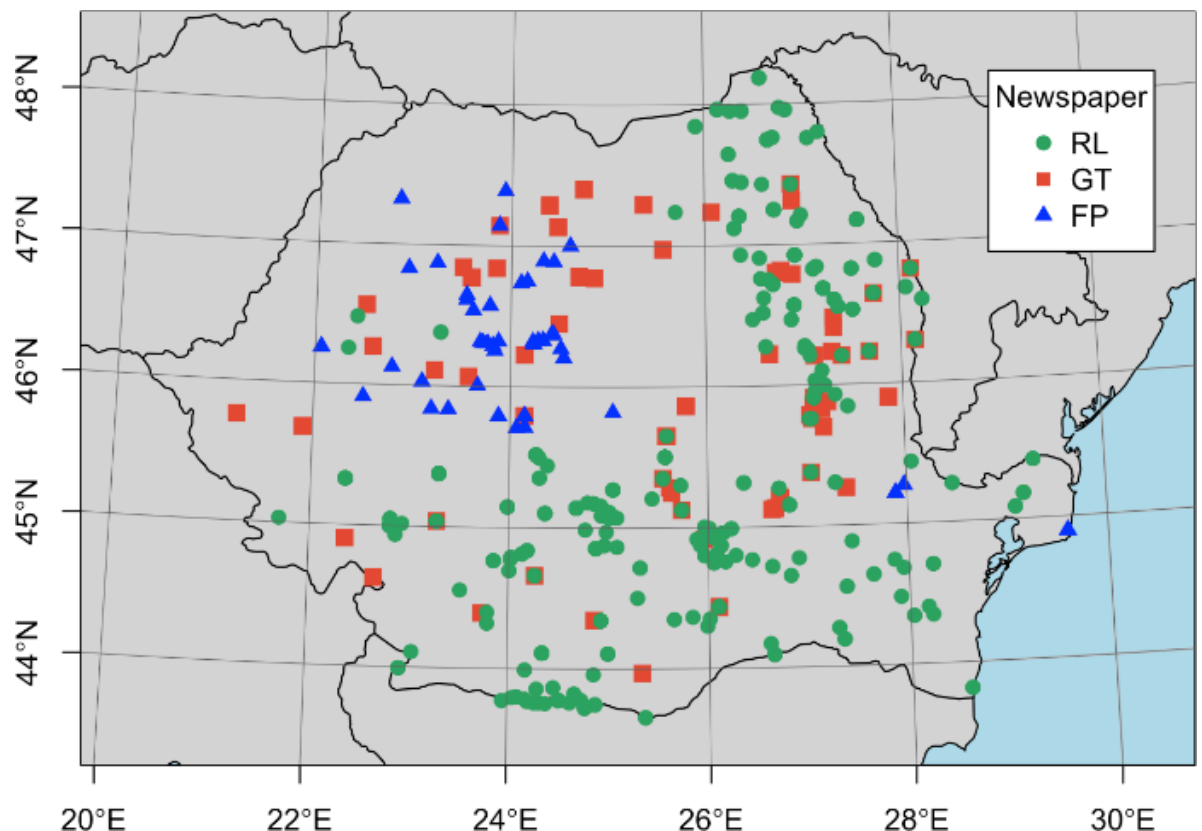

461 Figure 9 Spatial distribution of the rainfall events mentioned in GT, RL and FP reports (1879-1900) 
465 Table 1 Absolute and relative frequency of newspaper issues containing meteorological information from

466 total number of newspaper issues. Number of weather events selected for this study

\begin{tabular}{lcccc}
\hline $\begin{array}{c}\text { Newspaper, abbreviation } \\
\text { and source website }\end{array}$ & $\begin{array}{c}\text { Examined } \\
\text { period }\end{array}$ & $\begin{array}{c}\text { Total } \\
\text { issues per } \\
\text { newspaper }\end{array}$ & $\begin{array}{c}\text { Issues containing } \\
\text { meteorological } \\
\text { information from } \\
\text { the total number of } \\
\text { newspaper issues }\end{array}$ & $\begin{array}{c}\text { Number of } \\
\text { unique entries (1 } \\
\text { entry }=\mathbf{1} \\
\text { weather event / } \\
\text { locality) }\end{array}$ \\
\hline $\begin{array}{l}\text { România Liberă (RL) } \\
\text { http://www.digibuc.ro/ }\end{array}$ & January $1885-$ & 1004 & $221 / 22.0 \%$ & 1454 \\
$\begin{array}{l}\text { Gazeta de Transilvania (GT) } \\
\text { http://dspace.bcucluj.ro/ }\end{array}$ & $\begin{array}{l}\text { January } 1879 \\
\text { December } 1900\end{array}$ & 5005 & $336 / 6.71 \%$ & 796 \\
$\begin{array}{l}\text { Foaia Poporului (FP) } \\
\text { http://dspace.bcucluj.ro/ }\end{array}$ & January $1893-$ & 389 & $78 / 20.1 \%$ & 271 \\
TOTAL & December 1900 & & & \\
\hline
\end{tabular}

468 Table 2 List of weather events identified in the newspapers of the 19th century grouped by categories.

\begin{tabular}{|c|c|c|}
\hline \multicolumn{2}{|l|}{ Meteorological events } & \multirow[t]{2}{*}{ Category } \\
\hline Romanian terminology & English terminology & \\
\hline $\begin{array}{l}\text { Vreme caldă, căldură, temperaturi mari, caniculă, } \\
\text { căldură tropical }\end{array}$ & $\begin{array}{l}\text { Warm weather, hot, high } \\
\text { temperature, heat, tropical warm }\end{array}$ & High temperature \\
\hline Vreme rece, timp rece, frig, temperaturi mici, ger & $\begin{array}{l}\text { Cold weather, coldness, low } \\
\text { temperature, frost }\end{array}$ & Low temperature \\
\hline $\begin{array}{l}\text { Ploaie, timp ploios, Ploaie torențială / abundentă / } \\
\text { intense }\end{array}$ & $\begin{array}{l}\text { Rainfall, heavy / abundant / } \\
\text { intense rainfall }\end{array}$ & Rainfall \\
\hline Orcan, uragan, ciclon, furtună, vijelie & $\begin{array}{l}\text { Hurricane, (heavy) storm, } \\
\text { cyclone }\end{array}$ & Storm \\
\hline Tunet & Thunder & Thunderstorm \\
\hline Fulger, trăznet, descărcări electrice & Lightning & \\
\hline Furtună cu trăznet, furtună cu tunet, vijelie & Thunderstorm & \\
\hline Inundaţii, ape mari, viituri, vărsare de apă & Flood, flash flood & Flood \\
\hline Secetă, uscăciune & Drought, dryness & Drought \\
\hline Vânt, vânt puternic, vijelie, vânt violent & Wind, wind gusts & Wind \\
\hline Tornadă, tromba & Tornado, waterspout & Tornado \\
\hline Ninsoare & Snowfall & Snowfall \\
\hline Zăpadă & Snowpack & Snowpack \\
\hline Viscol & Blizzard & Blizzard \\
\hline Grindină & Hail & Hail \\
\hline
\end{tabular}


Brumă

Sloiuri de gheață

Marea înghețată

Topirea zăpezii, topirea gheții

Ceață

Foc de vegetaţie
Frost roar

River ice

Sea ice

Melting snow, melting ice

Fog

Wild fire
Frost roar

River ice*

Sea ice

Melting snow

Fog

Wild fire

*A distinct category is dedicated to the ice on Danube, namely Danube ice 